\title{
Wakf in the socio-economic structure of Azerbaijan, the place of Wakf property (on the basis of archival materials of Etchmiadzin monastery)
}

\author{
Mehman Abdullayev \\ Assoc. Professor of the Baku State University, Baku, Azerbaijan
}

Email address:

demoqraf@rambler.ru,mehmangehreman@mail.ru

\section{To cite this article:}

Mehman Abdullayev. Wakf in the Socio-Economic Structure of Azerbaijan, the Place of Wakf Property (on the Basis of Archival Materials of Etchmiadzin Monastery). History Research. Vol. 2, No. 2, 2014, pp. 7-10. doi: 10.11648/j.history.20140202.11

\begin{abstract}
In 40 years of XIX century the core of Armenian catholicons from territory of Ottoman Empire was rescheduled to Azerbaijan region. In this article in appropriate of historical source by evidenced detail analyzing such problem as converting Armenian catholicons in protection of Azerbaijan rulers in the grand Wakf properties, increases of this properties and transform them in property of Etchmiadzin due by Azerbaijan Turks properties. The main propitious ness of Erivan khan was used Armenian catholicons. It is confirming by various evidence, and also synchronies by Armenian source. In this article there are detailed working out edicts by Erivan Huseynali khan from 1760 year (consist of 14 paragraph) where legalized the rights on Wakf properties of Etchmiadzin, liberty of these possessions from taxation and their inviolability. Using by Muslim graces Armenian religion activities in all sorts of opportunities oppressed Turks population, as the matter of fact Etchmiadzin catholicons didn't permit to build the dwellings and to create industry to Azerbaijanis peasants on distance far from monastery territories.
\end{abstract}

Keywords: Wakf, Karabakh, Khanate of Erivan, Etchmiadzin

\section{Introduction}

In present article based on first source there were investigate the place of Wakf properties in agrarian and social - cultural lives in Azerbaijan duration of khan and subsequent periods of their status, role in existing agrarian attitudes. There mainly attention is paid to such less study in Azerbaijan historiography question about numbers of clerics in Karabakh Khans based on cameral inscriptions.

The purpose of the Wakf property, Muslim religious land belonging to religious institutions and the activity of Etchmiadzin monastery in the period of khanate, was also investigated with original sources in this article.

\section{Definition of Wakf}

History of Wakf lands is measured for the centuries in Azerbaijan, which origin comes from the Arab Caliphate. Prominent Azerbaijani historian Ziya Bunyadov, calling Wakf as a "property of Allah," wrote that people could only use the property, but did not have them any personal rights. [3, p. 152]. Belonging to religious institutions, mosques, madrasas [religious school], churches and monasteries, Wakfs included not only lands of their location, but also caravanserais, shops, oil wells and other property. According to sharia [religious laws], wakf forbidden to turn into an object of sale or donate it. [3]

Wakf was the part of the land and property in the Azerbaijani khanates at the second half of the XVIII century. Wakf ownership of the Bibi Heybat mosque included oil wells of Shikh village, located on the seafront and preserved since the Safavids and village gardens Zych. [1, p. 9-10; 7, p. 137]. Wakf ownership of Shusha mosque, built by Ibrahim Khan's daughter Gevher Agha, consisted of four villages. [7, c.137] The Wakf land of the Imamzade mosque, located in the Ganja Khanate, was 1,200 hectares [1,182 acres and 2152.5 sazhens]. [9, p.341] In the Karabakh khanate Gandzasar monastery, which belonged to Christians of Albanian origin, owned Wakf of 5 villages. [2, p. 43]. Wakf property of the Sheikh Safi mausoleum, located in the Ardabil Khanate, included twenty percent of the Khanate lands. [4, p. 84] According to the studies of population census of the Karabakh khanate's mahals [district] in 1823, there were 191 families of the Muslim religious clergy, which included 182 molla, five Seids, two Effendis, Akhund 
and a dervish. Out of 42 religious figures of the city of Shusha were 20 molla [religious rank], 19 Seids [religious rank], 2 Akhund [religious scientist], Gazi [religious judge] and 2 Caliph. Out of 44 families of religious figures living in Shusha, only two were Christian. [11, p. 1- 412]

From the 18,563 families residing in the Karabakh khanate, 302 belonged to the religious leaders. [11, p.1-412].

\section{The True Aspects of the History of Etchmiadzin Monastery. Way Leading to the Armenian-Azerbaijani Conflict}

During the period of khanate, along with Muslim religious departments and religious institutions, Christian churches and monasteries were considered as land and property of Wakf. Among these Wakfs, especially allocated Etchmiadzin [Uchkilse] Monastery, which was located in the ChukhurSaad beylerbeylik [principality] of Azerbaijan. As a result of misstep of the Azerbaijani ruler - Jahan Shah, who did not consider the future of Turkish -Muslim population, Armenian Catholicos was relocated from Sis city of Cilicia region of the Ottoman Empire to the Erivan in 1441. For more than 300 years, capturing, buying and receiving remuneration as Wakf owned villages belonging to Azerbaijani Turks, land, orchards and vineyards, Armenian Catholicos created large monastic farm, known as Uchkilse [Etchmiadzin]. [8, p. 113 - 114]. According to the information of I.P.Petrushevsky, a part of Etchmiadzin Monastery was the owner of 22 villages [ 26 villages are also included - M. A], acquired through purchase or donations with Mulk rights in the XVIII century. [10, p. 234]. In fact, these lands were Wakf. Simeon of Erivan, who led Etchmiadzin Monastery from 1763 to 1780, in his work "Jambr" or "Dzhambr" [means papal archive - M. A] gives many facts and information about buying and assigning different ways in the Turkic-Muslim population of many villages, arable land and other property from the moment Armenian Catholicos appearance in Erivan until eighteenth century. [5]. Analysis of the information which is contained in the materials of this work shows that the document of ownership on purchased from the land of the Azerbaijani population, prepared and approved in Sharia courts, and stamp these documents posed Gazi or Sheikh-ul-Islam [religious leader], who was sitting in the Chukhur-Saad belerbeylik [principality] - the center of Erivan. [5, p.171173, 177-199]. Simeon of Erivan given full information about the villages of Ashtarak, Batrindzh, Naragavit, Agunatun, Kireshli, Mugina, Mastara, Oshagan, Kultepe, Yaychy, Saatli, Chichekli and others acquired from the Azerbaijani Turks Etchmiadzin Monastery since the midfifteenth century until the late XVIII century. [5, p.171-199]. The names some of these villages are not clear for us, without a doubt, due to the attempts of the Armenians already replaced Turkic toponyms at that time. This fact could not hide him Simeon of Erivan. Oshagan village, which he presented as an Armenian, was surrounded on one side Garakilse [in Turkic the Black Church] in the Hajilar village, and on the other side of Shahverdi channel. The third was Turkey. The fourth border reached to the Choki and Carpi. [5, p. 182]. Simeon of Erivan wrote that Khan's period in 1768, "with God's help we kicked Mughanli Muslims and Armenians settled in the village Gashagan." [5, p.183]. Armenian authors claim that all the villagers of Valarshabad what Simeon of Erivan calls the base of Echmiadzin Monastery, were the Azerbaijan Turks, and none of the Armenians live here. [8, p.118]. The materials Uchkilse noted that known as Keshishkend village, originally called Aydyndervish and located in Magal Gyrhbulag and another village Chelebikend at different times were bought from Azerbaijanis by Armenian Catholicos, as the territory of the Muslim population. For example, the village Aydyndervish, which is property of Gyulismail Agha, was bought by Catholicos Akop within 6 dangs [land area] to 2 tuman. During the period of khanates of the village around the four sides were the Turkic-Muslim villages Armudagadzhi, Ilanly, Guruludere and Garadash. On the borders of the Azerbaijan village Garagoyunlu, which was renamed Elkyasan, were Goyunluhasar village, and Alibabat Imamsherli. [5, p. 198]. It should be noted that, since the mid - XV century, along with many of the property allowed paper [gabala], which confirms the ownership of the monastery on Uchkilse, taken from Azerbaijanis in various ways, 26 villages, numerous pastures, canals, vineyards, mills and other property, there were also decree [farman] signed by the Safavids shahs [Shah Abbas I, Shah Abbas II, Suleyman Shah, Shah Sultan Hussein and others, well as by Nadir Shah Afshar], also confirming the right of Uchkilse on wakf ownership. Most of the property allowed papers and decrees, especially issued by the Safavids, were written in the Azeri language. [5, p. 191, 201, 203, 209, 343, 329-347]. In 40s of the XVIII century, established on the lands of Chukhur-Saad beylerbeylik [principality] of Azerbaijan and the Erivan Khanate, the monastery Uchkilse as a Wakf ownership not only retained its former rights and status, but also further strengthened its position by using favor of the Erivan Khan.

\section{The Decree of 1760. The New Period of the Echmiadzin Monastery's History}

According to the decree of Huseynali Khan of Erivan signed in 1173 Hijri [1760] issuing this decree based on the decree of Safavids shahs and other rulers, confirmed the inviolability of Echmiadzin [Uchkilse] Monastery as a Wakf ownership. This decree, consisting of 14 points, said:

"1. Echmiadzin Caliph, all the inhabitants and all property is considered to be as wakf, no one dares to demand from them a single dinar, all arable land [Etchmiadzin] and cereal crops should not shall be measured. So it was and should continue. 2. If Armenians and Muslims from the Erivan area will sow the land [belonging] Etchmiadzin, the property they have to pay the caliph, as required by law. 3 . In Echmiadzin 
[Uchkilse] and all other monasteries and churches Armenians are free to sound the alarm and rivet, bury their dead, to convene a church, crying to conduct services in the monasteries and churches. 4. If someone illegally took possession Uchkilse wakf or purchased, it should return them. 7. If someone sold Echmiadzin property or gave him a wakf, after his death, his relatives don't have right to sue and sold wakf property. 9. Muslims have no right to forcibly Islamized Armenians pay. 12. Neither Muslims nor Armenians should not sow Etchmiadzin fields, vineyards, or other land or assign them. 13. Half river Oshakan [Kasakh] belongs to Etchmiadzin and half - the rest of the villages, so the Shah's decrees established anciently, so should remain so. 14. Members of the Shah's decree Etchmiadzin brethren from time immemorial recognized magafs. Therefore they are taken out of inventory and do not have to pay someone else. [5, p. 306-308].

\section{The History of the Monastery in the XVIII Century}

The agriculture of the Etchmiadzin Monastery has increased significantly during the khanate period in the XVIII century. The Monastery owned arable land 190 khalvar [375 ha] [1 khalvar $=1.97$ hectare], of which 103 khalvar seeded annually [12, p.71-72]. In order to show the evil methods that were used in building such a huge property and large farms, should appeal directly to playing the role of undisputed source book of Armenian author. Simeon of Erivan wrote: "The Holy See has extensive lands outside our village, south of the Black River [Armenians called her Metsamor - M. A] ... this flows through the area and enters into the great river Araks. Safi Khan II ... sits in Erivan at the behest of Shah Suleiman. This Safi Khan conducts the river Metsamor ... big ditch ... and his wife ... takes away from its large custom channel ditch in the same area... This water we had and gave a wakf ... Those who will sow the land irrigated from our channels, whether local villagers or aliens from other places, the Muslims or the Armenians, who are exempt from paying whatever one tenth from their crops, for the water we grant free. And it continues to this day." [5, p.230]. Grand Canal, passing through the village Alibeili, crossed the river Oshagan that emptied into the river Karasu and formed fertile ground covered island surrounded on all sides by water, on land which could grow vegetables and rice. This island belonged Alibeili village and water Sefiabad village. Catholicos Astvatsatur, head of the Uchkilse Monastery, purchased the same land as pasture for 25 tumans [the official currency of Safavids] from villagers Alibeili. On this occasion was composed gabala in the Azeri Turkic language. However, two years later, the inhabitants of these lands Alibeili demanded back. Catholicos notified the Muslim population of the village, he gave them 25 tumans, and 15 thousand dinars spent on legal fees. If the peasants returned 26.5 tumans, they can get back their land. Farmers who do not have the means, Catholicos asked to give up part of money. Catholicos remitted 14 tumans. He receives a written document, consisting of the two conditions from residents for payment of 12 tumans with the testimony of Erivan's Sheikh al Islam. "First, you have a period for so many days, during which you have to pay 12 tumans and get back their land, if he does not pay, the land remains in the Monastery. Secondly, getting back to the land, you have no right to sell it, but if you want to sell it, then you have to sell it to me and no one else." [5, p.231]. Naturally, the true owners of the land the villagers Alibeili, left without protection of the Erivan Khan, for 18 years could not pay the 12 tumans and were forced to abandon their land in favor of the Etchmiadzin Monastery located in the Azerbaijani lands. According to the gabala, composed in Azeri Turkic language in 1736 [hijri 1148], the land and property of the village Alibeili were transferred to the monastery. [5. p. 232]

In 1747, after the formation of Erivan Khanate, two Azerbaijanis, who changed the Alibeili village as their own property, demanded $1 / 10$ of taxes from Khatynarkh, which belonged to the monastery. Catholicos, based on evidence of Sheikh-ul-Islam, was able to obtain from Huseynkhan khan seal certified document that confirmed the land belongs to the monastery and there is no right of any person to dispute this property or require anything from these lands. [5, .232].

The Catholicos of Etchmiadzin did not allow building homes and creating economy by the Azerbaijani Turkic peasants even at a distance from the monastery grounds. In 1766, several residents of Muslims started to build a house in his native village Kultepe. Head of Etchmiadzin Simeon recognized with concern that this could create a problem for the Armenians. He follows described event: "We went there and noticed that they hastily built houses and learned that they promised property from his village Haji Mirza, son of our Hussein Ali Khan. Learning of this, we went to Hussain Ali Khan ... Khan ordered immediately to destroy buildings and to disperse the peasants. So they [Azerbaijani Turks] rejected. Then we bought this village from our Huseynali Khan. "[5, p. 269]. Simon writes about the expulsion of Kolany [Turkic] tribe, which is near the Etchmiadzin Monastery and farming, from Erivan. "A lot of us were worth the hassle of a written order to achieve the aforementioned Khan [Khan Huseynali - M. A.] by virtue of which we destroyed their lair and removed them from there, leaving no trace." [5, p. 233].

The Monastery strongly hindered Azerbaijani farmers to use irrigation systems and canals belonging Khanate. In the application of the villagers Kultepe to the ruler of Erivan Khanate - Farzali Khan, said: "80 years we have lived in this village and we constantly sown bread in their fields, but now residents of Etchmiadzin let us." After that Khan appointed and sent to investigate in this village eshikaghasi [the head of the village] Nadzhafali bey. [5, p.234]. According to Simon's writings, the land of Shehribanly, located near the village Kultepe, in the edge of the brook, as well as the land between Turabhasar and Nur Muhammedhasar were transferred Etchmiadzin as pastures. Lands, west of the canal transmitted inhabitants of Kultepe as pastures and deal in farming here 
they were forbidden. In addition, the villagers had to pave the way to a watering place for cattle monastery from top to Turabhasara nearby lake. Anyone who violates this edict paid a fine of 50 tumans to the khan's treasury. [5, p. 234].

The above information, about a fraction of troubles that have befallen on the head of the Turkic-Muslim population by Armenian religious leaders in the Erivan Khanate, is only a part of the documentary materials to bring facts and evidence.

\section{References}

[1] Azərbaycan Respublikası Mərkəzi Dövlət Arxivi (ARMDA) fond 31 , iş 48 , v.9-10

[2] ARMDA, f 55, s.1, iş 12, v.43

[3] Bünyadov Z. Azərbaycan VII-IX əsirlərdə. Bak1, "Şərq-Qərb", 2007, 489 s.

[4] Dəlili H. Azərbaycan Cənub xanlıqları. Bak1, Elm, 1979, 143 s.

[5] Ереванци Симеон. Джамбр. Памятная книга зерцало и сборник всех обстоятельств святого престола Эчмиадзина и окрестных монастырей. М., Издательство восточной литературы. 1958, 399 с.
[6] Oliyev F, Həsənov U. İrəvan Xanlığı. Bakı, "Şərq-Qərb”, 2007, 141s.

[7] Hüseynli R. Azərbaycan ruhaniliyi. (Xanlıqlar çağından sovet çağınadək olan dövrdə) Bakı, "Kür" nəşriyyatı, 2002, 266 s.

[8] The İravan Khanate. The Russian occupation and the relocation of Armenians to the lands of North Azerbaijan. Academic editor: Y. Mahmudov. Baku, Azerbaijan, 2010, 617 s.

[9] Колониальная политика Российского царизма в Азербайджане в 20-60-х годах XIX века. Ч. 2, Изд. АН СССР, М.-Л., 1937, 420 c.

[10] Петрушевский И.П. Очерки по истории феодальных отношений в Азербайджане и Армении в XVI начале XIX вв. Ленинград, Изд. ЛГУ, 1949, 379 с.

[11] Qarabağnamələr, I kitab. Tərtib edən və çapa hazırlayan A. Fərzəliyev. Bakı, "Yazıçı", 1989, 192 s.

[12] Егиазаров С.А. Очерки по истории учреждений в Закавказье, Т.1, Сельская община: Сословный строй внутренняя организация и управление общины и связь с земледелием, водовладением и податным обложением. Ч.1, Казань: Тип. Императорского Унив-та, 1882, 332 с. 